\title{
Negativization in Bassa Language
}

\author{
Imoh Philip Manda*
}

\section{Abstract}

Bassa language is classified as belonging to Kainji family under the sub-phylum Western-Kainji known as Rubasa (Basa Benue) (Croizier, and Blench, 1992:32). This paper discusses three basic strategies used in negativizing sentence structures, two of which attach to the verb stem as negative operators whereas the third operator is a particle which is not necessarily an affix. The general negative marker -shì is commonly used to negate an affirmative clause, tà- also attaches to verb stem to negate an imperative clause, and tà particle is used to negate perfective structures. All of these operators negate affirmative expressions and not only the verbs in questions but the whole clause. Where a perfective marker applies in a perfective tense, it precludes the attachment of the general negative marker; consequently the functions of both perfection and negation are fused in the particle tà.

http://dx.doi.org/10.4314/ujah.v13i1.6

\section{Introduction}

The Bassa people are in all the Federal Capital Councils: Kwali, Abaji, Gwagwalada, kuje, Bwari, Munucipal; Kogi; Nasarawa; Niger; and Benue states. The Bassa in Kogi are found in Bassa, Dekina, and Ankpa Local Government Areas; Niger, in Kontagora Local Government; Nasarawa, in Nasarawa, Kokona, and Toto Local Government Areas. According to 2008 census, Bassa had the population of 224839 (National Population Commission 2008). This is highly disputable as many people believe the population of Bassa triples that figure.

Bassa language is one of the Nigerian languages that are highly under-defined or under-described compared to 
larger languages like Yoruba, Igbo, Hausa, Ibibio, Effik etc. Bassa language has orthographies designed by missionaries who were non- linguists for the sole purpose of translating the Bible and other Christian literatures such as the Pilgrim's Progress (authored by John Bunyan), the Way of Salvation, abstracts of the Bible, etc. This they did by devising primers to enable users of these materials to learn how to spell, read and write. Apart from long essays written by some undergraduates and the researcher's M.A. thesis titled 'Aspects of Bassa Morphology', no further scholarly works have been done on this language. This work is purely a descriptive one. It studies the strategies for negativizing affirmative sentences in Bassa language. There are three strategies employed for negativizing affirmative sentences in Bassa language. The first one is -shìo, which is the general negative marker. It is the most productive strategy of negation in this language. The second one is tàwhich attaches to the verb stem as a suffix and the third one is the particle tà which pre-modifies the verb stem to negativize an imperative sentence.

The choice of this topic in Bassa is motivated by the fact that studies on negative constructions in most African languages is not very popular and some people are completely ignorant of the interesting operations underlying this aspect of linguistics. And in Bassa language, to the best of my knowledge, no one has investigated into this area of the language. This descriptive study will add to the existing knowledge in the linguistic literature and create an awareness of how it operates in Bassa language.

The following are methods used to source for data in this study:

i. Blench's 1017 wordlist is used as the primary source of generating data for this study: The researcher engaged native speakers of Bassa language to fill the wordlist. 
ii. The researcher, being a native speaker of the language, used his native intuitions corroborated by inputs from other native speakers.

iii. Data were sourced from works on morphological, syntactic, and morphosyntactic theories

iv. Other relevant linguistic and non-linguistic materials such as the Bassa Bible, hymns etc. were also used as a means of gathering data for this work.

v. The researcher also observed other native speakers and interacted with them to study features of morphosyntax as it pertains to negativization.

Negation which is claimed to be a distinct speech act from the affirmative is an area of interest in syntax which has attracted scholars (Ndimele, 2005:95). Morava (1977:168) quotes Garcia (1975:8) as saying that "negative sentences communicate in terms of an implicit, but rejected, affirmation which might be expected to hold, but which in fact fails to obtain."

Morava (1977:168) states that "while affirmatives are used to convey new information on the presumption of ignorance of the hearer, negatives are used to correct misguided belief on the assumption of the hearer's error."

Scholars have defined negation in different ways. Anagbogu (2005, 575) quotes Crystal 1996:243; Watters 2000:208; Oluikpe 1976: 164 and Heasley 1983:19) as saying "negation is a grammatical process by which an affirmative sentence is negated." A negative sentence must have a negative operator in form of an affix or a full word (Anagbogu, 2005:29).

It has a process or construction in grammatical and semantic analysis which typically expresses the contradiction of some or all of a sentence's meaning (Crystal, 1994:131; 2008:323). Lyons (1968) defines it also as a denial of a positive proposition, or a prediction that a proposition is 
untrue. Payne (1997:282) observes that the function of negation is to negate the clause which asserts an affirmation of an event, situation, or state of affairs.

Ndimele (2005:95) quotes Schaefer and Masagbor (1984:28) defining negativization "... in terms of the truth value of two sentences that is, a negation marker is such that in converting one sentence (S-1) into another (S-2), it brings about a state where $S-1$ is true if $S-2$ is false or S-2 is true if S1 is false." This implies that, sentence-1 is untrue if the other (sentence-2) is true. For example, Bill arrived early (1) vs. Bill arrived late (2). The state in the example above is that, sentence (1) is true only and only if sentence (2) is false.

Generally, there two types of negation in the linguistic literature: clausal negation which negates the whole proposition of a sentence and lexical negation which negates only a constituent (Payne, 1997:282, Anagbogu, 2005:575). Although these two are very similar or identical, this work focuses on the first.

Bassa language offers very rich morphosyntactic processes of negation. This paper presents an examination of the basic features of negation in Bassa language. It is divided into three sections. The first section is the introduction. The second section analyses the various processes of negation marking in Bassa. Section three is the conclusion.

\section{The Morphosyntactic Features of Negation}

Bassa has several ways of expressing negation such as:

* Negative inflectional suffix

* Negative inflectional prefix

* Inherently negative particle

\section{Negative Inflectional Suffix}

In Bassa, the main strategy for expressing negation is through the use of negative inflectional suffixes which are attached to the verb stem of the lexical or auxiliary verb to express this 
morphosyntactic function. Once a negative suffix attaches to a verb, it negates the whole structure.

\section{General Negative Marker}

In Bassa language, the main or primary negation strategy is the attachment of the negative inflectional suffix -shiò to the verb stem/root and auxiliary verbs. The negative suffix is used in all tenses, aspects and mood. Being the primary negation strategy, it has the widest distribution in Bassa language vis-à-vis other negative marking strategies or processes. This can be exemplified as follows:

a. Bì

shiteji

ìyìmyẹ

3SG SBJ Cook PST food

'S/he cooked some food'

b. Bì

shítejíshi

ìyìmyẹò

3SG-SBJ

cook-PST-NEG

food-NEG

'S/he

did not cook food'

(2)

a. Gà Jére so ọhàntò

NOM Jére buy-PST boat/plane

'Jerebought a boat/plane'

b. Gà Jére sé-shi ọantòò

Nom Jére buy-PST-NEG boat/plene-NEG

'Jére did not buy a boat'

a. Tí zhe ta rità utakàda

1PL-SBJ AUX AGR read-PRES book

'We will read a book'

b. Tí zhá-she ta rità utakàdaò

IPL SBJ AUX NEG AGR read-PRES book-NEG

'We will not read a book' 
a. Ẹè zhẹ a rità utakàda 3PL-SBJ AUX AGR read-PRES book 'They will read a book'

b. Aà zha-shẹ a rità utakàdaò 3PL-SBJ AUX NEG AGR read-PRES book-NEG 'They will not read a book'
a. Botò áta zhẹmẹ 3SG that fine/beautiful
'That person is fine/ beautiful'
b. Botò ata zhé-shio
3SG that good
'That person is not fine'

This negatization process can be expressed in the following rule as proposed by Anagbogu 2005.

$[\mathrm{VR}[\mathrm{NM}] \mathrm{VS}] \longrightarrow \mathrm{NEG}$

[ shiteji] vR [ shi] NM ] ] vs $\longrightarrow \mathrm{Bi}$ shitejishi iyímyẹ 3SG cook-PST food 'S/he cooked food'

Where VR stands for verb root; NM, negative morpheme; and VS refers to verb stem.

In the foregoing examples, the negative suffixes attach to the verbs stem express negation. In (1b) and (2b), the general negative suffix attaches to the verb stem of a non-stative verbs, in (3b) and (4b) it applies to auxiliary verbs while in (5) it attaches to a stative verb. It is interesting to note in the foregoing illustration that in the affirmative sentence (a) the verb stems are of a mid tone (unmarked) but when the negativizing prefix applies, the tone changes from mid to high. Furthermore, we earlier stated that the negativizing affix is shio, but where a sentence is made up of a transitive verb, the 
negativizing element splits into two i.e - sh $i$ - $-o$, - shi attaches to the verb root and $-o$ attaches to the object of the transitive verb, as in example (2b); note the additional vowel to òhantòo.

Finally, the negativizing affix is the last layer of affixes (i.e. that attaches to the verb stem); all other suffixes precede the negativizing affix. For example, where other suffixes apply to the verb stem such as applicative to show location, dative or benefactive case; causative affixes, etc, the negativizing suffix applies last in this sequence. This can be exemplified as follows:

a. Bì shitegeni bò iyimyẹ

3SG SBJ cook-PST APPL3SG food

'S/he cooked some food for him/her'

b. Bò shítegeni-shi bò iyimẹyẹò

3SG cook-PST-APPL-NEG 3SG food-NEG

'S/he did not cook food for him/her'

(7)

a. Gà Laso wecicinji yẹu

Nom Laso lie-PST-CAUS child

'Laso made/cause the baby to lie'

b. Gà Laso wácicinji shi yẹuo

NOM Laso lie-PST-CAUS NEG child-NEG

'Laso did not make/cause the baby to lie down'

Baertsch (2001:67), notes that the presence of the negative marker yo? in Lamso causes the loss of certain tense markers. Morava (1977) equally observes that in Swahili, temporal distinctions often neutralize in the negative. In Bassa, the presence of negative marker forestalls the application of a perfective marker. In the affirmative sentence, the suffix -wo is added to a verb stem to mark perfective but when a negativizing morpheme applies, the perfective marker is no longer applicable. This can be exemplified in (8) and (9) below: 
(8)
a. Tó
lasò
1PL SBJ win PST
'we won'
b. Tó
lasòwọ
1PL-SBJ win-PERF
'We have won'
c. * Tó lásowosuo
1PL SBJ win-PERF-NEG
'We did not win'

(9)
a. Aà
yẹ
iyimyẹ
3PL-SBJ eat-PST
food
'they ate some food'
b. Aà
yẹwà
iyimyẹ
3PL-SBJ eat-PERF food
'They have eaten
food'
c. *Aà yéwashẹ
iyimyẹo
3PLeat-PERF-NEG
food NEG
'They have not eaten food'

In the foregoing we can observe that once a negativizing marker applies, no other suffix applies, hence the ungrammaticality of (8.c) and (9.c) respectively.

\section{Negativizing Perfective Verbs}

The negation of perfective verb form is marked by ta particle which occurs before the perfective verb form. In this case $t a$ is not an affix bound to the verb form rather it is an independent morpheme like the English negative operator not.
(10)
a. Bù
so
ùhantò
3SG SBJ buy PST
boat/plane
'S/he bought a boat/plane' 

b. Bù
sowo
ùhantò
3SG SBJ buy PERF boat/plane
'S/he bought a boat'/plane'
c. Bù
tè
se-shi
ùhantòo
3SG-SB PERF-NEG buy-NEG
plane-NEG
'S/he has not bought a boat'

(11)

a. Gà Ábwa nje ùgondu NOM Ábwa do-PST work

'Abwa worked'

b. Ga Ábwa nduwa ugondu NOM Ábwa do-PERF work 'Abwa has worked'

c. Gà Ábwa tà njé-shẹ ugonduò NOM Ábwa PERF-NEG do-NEG work NEG 'Abwa has not worked

a. Tú

swe meni 1P-SBJ drink-PST water 'We drank water'

b. Tú sówo meni 1PL-SBJ drink-PERF water 'We have drunk water'.

c. Tú te swé-shi meniò 1PL-SBJ PERF-NEG drink-NEG water-NEG 'We have not drunk water'

In the foregoing example (10.c) to (12.c) we can observe that to negativize a perfective structure since the negative marker does not co-occur with a perfective marker in the same verb stem, the particle ta (or te, depending on the initial sound of the verb stem) is employed to mark both negation and perfection such that the gloss indicates negation in three different places. There are actually two negative elements but since we earlier observed that -shiò, the general 
negative marker splits when the verb is a transitive one, hence

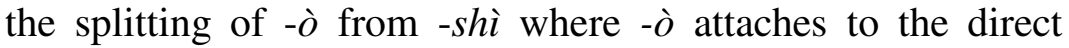
object of the transitive verb and -shi remains with the verb stem. Furthermore, because the suffix -shiò is the last layer that applies to the verb stem, the perfective marker -wo has to delete to give way for the general negativizing element where its function is fused together in $t a$ which is equally a perfective marker.

\section{The Negative Anticipative Verb Form}

The anticipative verb in Bassa is indicated by zha. It is an auxiliary verb which is used in the affirmative to express simple future. To form a negative form of a simple future, the general negative suffix -shiò is attached to an auxiliary verb $z h a$. It is also note worthy that -ò splits from -shì as earlier observed but in this case to either attach to the lexical verb as a suffix for intransitive verbs or to the direct object in the case of transitive verbs. Examples:

a. Gè Gèbi zha sa umotu NOM Gèbi ANT buy car

'Gebi will buy a car'

b. Gè Gèbi zha-shẹ sa umotuò NOM Gèbi ANT-NEG buy car-NEG 'Gebi will not buy a car'

a. Bí zhe ba zha udukwo 2SG-SBJ ANT AGR go market 'You will go to the market'
b. Bí zhá-she ba zha udukwo-o 2SG-SBJ ANT-NEG AGR go market-NEG 'S/he will not go to the market'

(15) a. Òshilo zhe o ngbo hwayẹ gaà rain ANT AGR fall day this 'It will rain this day/today' 

b. Òshilo zhá-shẹ o
ngbo hwaye ga-o
rain AN-NEG AGR fall day this-NEG 'It will not rain today'

(16)
a. Hí zhẹ hia zhàjẹbèyi
2PL-SBJ ANT AGR come tomorrow
'You will come tomorrow'
b. Hí zhá-shẹ hia zhajẹ beyi-o
2PL-SBJ ANT-NEG AGR come tomorrow-NEG
'You will not come tomorrow'

We can draw the following morphosyntactic observations from the foregoing illustrations:

i. The negativizing suffix (-shì) is hosted by the auxiliary verb which shows anticipation.

ii. Examples (14) and (16) have the particles ba and hía respectively, which are subject agreement markers which serve as resumptive pronouns in pronominal situation.

iii. The morphemes $b a$ and híá in (14 and 16) respectively show agreement with their subjects. In Bassa, first person, second person and third person always marked with an agreement marker. The consonants of these markers always agree in place of articulation with their heads, hence $b a$ in (14) and hía in (16) show agreement with bi and hía respectively. In situations where the subject is a proper noun such as names like (13), subject marking becomes optional.

\section{Negative Imperative}

The negative imperative or prohibitive (Ndimele 2005:948) is marked by tà in Bassa. This negativizing element is different from the general negativizing suffix -shio. Ta prefixes a verb stem, and is hosted by a lexical verb. This type can be exemplified below: 

(17)
a. Yá ijènè
eat yam
'Eat yam'
b. Tà ya ijènè!
PR-NEG-eat yam
'Don't eat yam'

(18) a. Swá taama

drink porridge

'Drink porridge'

b. Tà swá taama-o!

RR-NEG drink porridge

'Do not drink porridge!

(19) a. Ndá tinyecì

do writing

'write'

b. Tà ndá tinyeciò!

PR-NEG do writing

'Do not write'

\section{Conclusion}

From the foregoing discussion, we have seen that negation can be marked in different ways in Bassa language. We can highlight the following points as emerging from this investigation:

a. Some tense/aspectual distinctions made in the affirmative constructions get neutralized under negation. Negation causes a neutralization of tense forms in both the perfective and imperfective aspects. See Ndimele (2005:955) quoting Wilkendorf (1988:49)."

b. Apart from the morphosyntactic operation, we also observed that negation provokes changes in tone in Bassa. 
c. Three elements are basically used to mark negation in Bassa which are -shíò, ta- and tà. For -shíò which is the general negativizing element applies directly to the verb stem as a suffix, where the verb is a transitive one, -ò splits from -shi and applies at the right-most edge of the direct object of the transitive verb (as a suffix), but where the verb is an intransitive one the two (i.e -shí and -ò are fused together as one negativizing element. $T a$ - is also another operator that prefixes the verb stem to negate a clause and finally the particle tà pre-modifies the verb stem to negate an imperative.

d. In a situation where a sentence has an auxiliary verb, the negativizing affix zha 'will' attaches to the verb stem as a prefix.

All of these are the different ways of expressing this morphosyntactic process in Bassa language which negate not only the verb but the entire sentence.

*Imoh Philip Manda lectures in the Department of Languages and Linguistics, Nasarawa State University, Keffi. 


\section{References}

Anagbogu, P. N. 2005. The negativizing prefixes of Koring. In O.M. Ndimele (ed). Trends in the study of languages and linguistics in Nigeria: A festschrift for Philip Nwachukwu. Aba: National Institute for Nigerian Languages, pp.574 582.

Baertsch, K. 2001. Morphological and syntactic aspects of negation in Lamso. AAP 69, pp. $125-143$.

Crystal, D. 1994. An encyclopedic dictionary of language and languages Oxford: Blackwell.

Crystal, D. 2008. A dictionary of linguistics and phonetics. Oxford: Blackwell.

Lyons, J. 1968. Introduction to theoretical linguistics. Cambridge: Cambridge University Press.

Morava, E. C. 1977. What is a negative equivalent. Data from Swahili negative tenses. Studies in African language and linguistics supplement 7, pp.165 - 173.

Ndimele, O. M. 2005. Negation Marking in Igbo. In Ndimele O.M (eds) Trends in the study of languages and linguistics in Nigeria: A festchrift for Philip Nwachukwu. Aba : National Institute for Nigerian Languages. pp.939 - 956.

Payne, T. 1997. Describing morphosyntax: A guide to field linguistics. Cambridge: Cambridge University Press.

Schaefer, R.P., and R. Masagbor 1984. The form of negation. Journal of West African language xiv: 2, 2742.

Watters, J. R. 2000. Syntax. In Heine, B, and D. Nise (eds.) African language: An introduction. Cambridge: Cambridge University Press. pp.194 -230.

Wikerdorf, P. 1988. Negation in Nommande. Journal of West African Languages xviii: 2, pp.49-70.

Wikipedia Free Encyclopedia 2011. 